\title{
An EFL Coursebook Evaluation in terms of Design and Language: Private School Samples in Sinop*
}

\author{
Yeliz Yazıc1 ${ }^{\mathrm{a}}$ \\ Pelin Haytab \\ a Lect., Sinop University, ORCID: 0000-0001-8277-9246 \\ b Lect., Sinop University, ORCID: 0000-0003-1613-0785
}

\section{ABSTRACT}

This study aims to evaluate an English textbook in a private school example in Sinop. Although private schools and public schools follow the same curriculum, there are differences in the textbook preference. In this study, as an external evaluation, the English textbook was examined in terms of the design elements; and, as an internal evaluation, the book was examined in terms of the instructional elements. The research design was qualitative and the process was carried out by two different researchers. Results showed that although the textbook was found appropriate and effective based on the external evaluation: graphic design and print quality; the presentation of the four language skills in the textbook was poor. Reading skill was the most dominant skill presented, and writing skill was the least presented skill in the textbook. Therefore, the textbook needed supportive material to present other skills effectively. It is concluded that the textbook in this study is not suitable for teaching four language skills effectively and is not suitable for the purposes of the English language content as defined by the Ministry of Education.

\section{Article Type}

Research

\section{Article Background}

Received:

02.09.2020

Accepted:

08.12.2020

\section{Key Words}

Graphic Design,

Course book

Evaluation, English

as a Foreign

Language Teaching
\end{abstract}

To cite this article: Yazıc1, Y. \& Hayta, P. (2021). An EFL coursebook evaluation in terms of design and language: private school samples in Sinop. International Journal of Turkish Educational Sciences, 9 (16), 17 33.

Corresponding Author: Yeliz Yazıc1, e-mail: yaziciyeliz@gmail.com

\footnotetext{
"Ethics committee approval is not required for this study since it does not use any procedure including human or animal subjects
} 


\title{
İngilizce Ders Kitaplarının Tasarım ve Dil Açısından Değerlendirilmesi: Sinop'ta Özel Okul Örnekleri*
}

\author{
Yeliz Yazıc1 ${ }^{\mathrm{a}}$ \\ Pelin Haytab \\ a Öğr.Gör., Sinop Üniversitesi, ORCID: 0000-0001-8277-9246 \\ b Öğr.Gör., Sinop Üniversitesi, ORCID: 0000-0003-1613-0785
}

\begin{tabular}{lll}
\hline ÖZ & MAKALE BİLGİSI \\
\hline Bu çalışmada, İngilizce ders kitabının Sinop'ta özel bir okul örneğinde & \\
değerlendirilmesi amaçlanmıştır. Özel okullar ve devlet okulları müfredat & Makale Türü \\
olarak aynı müfredata sahip olmakla birlikte, okulların tercih ettiği ders & Araştırma \\
kitaplarında farklılıklar görülmektedir. Bu çalışmada, İngilizce ders & \\
kitabının dış değerlendirme başlığı altında tasarım öğeleri açısından; iç & Makale Geçmişi \\
değerlendirme başlığı altında eğitim öğeleri açısından incelemesi & Gönderim tarihi: \\
yapılmıştır. Araştırma tasarımı niteldir ve süreç iki farklı araştırmacı & 02.09 .2020 \\
tarafından yürütülmüştür. Sonuçlar, ders kitabı tercihinin dış & Kabul tarihi: \\
değerlendirme, grafik tasarım ve baskı kalitesi açsından uygun ve etkili & 08.12 .2020 \\
olmasına rağmen; ders kitabındaki dört becerinin sunumun zayıf olduğunu & \\
ortaya koymuştur. Okuma becerisi seçilen ders kitabında verilen en baskın & Anahtar Kelimeler \\
beceridir ve yazma becerisi en zayıf beceridir. Ders kitabının diğer becerileri & Grafik Tasarım, Ders \\
etkili bir şekilde sunmak için destekleyici materyallere ihtiyacı vardır. Bu & Kitabı \\
çalışmadaki ders kitabının, dört dil becerisini etkili bir şekilde öğretmeye & Değerlendirmesi, \\
uygun olmadığı ve MEB tarafından tanımlanan İngilizce dil içeriğinin & İngilizcenin Yabancı \\
amaçlarına uygun olmadığı söylenebilir. & Dil Olarak Öğretimi \\
&
\end{tabular}

Atıf Bilgisi: Yazıc1, Y. ve Hayta, P. (2021). An EFL coursebook evaluation in terms of design and language: private school samples in Sinop. Uluslararası Türk Ĕ̆itim Bilimleri Dergisi, 9 (16), 17-33.

Sorumlu Yazar: Yeliz Yazıcı, e-posta: yaziciyeliz@gmail.com

\footnotetext{
* Bu çalışma insan veya hayvan deneklerin yer aldığı herhangi bir prosedür içermediği için etik kurul onayı gerektirmemektedir
} 


\section{Introduction}

One of the main and supportive materials of the education is the course book selected for the specific lesson. Course books are important both for the teacher to conduct the lesson process more effectively and for the students to have a more productive academic period. (Zohrabi, 2011) Recently, it has been observed that education systems are more inclined towards the use of interactive boards and internet-based teaching materials with the new developments. Although it is a general tendency books are still among the most popular material in teaching English (Işık, 2013). When the opinions of teachers about the function of teaching materials were researched, it was seen that printed materials were still among the most preferred materials despite the items such as; online classrooms, interactive boards, virtual reality settings (Şahin, 2014). The main printed material in education is the course books and workbooks that were prepared and selected according to the level of students.

The course books have been evaluated and selected for many lessons and foreign languages are one of them. English Language has been taught at schools as on official lesson since 1869 (Güneş, 2009) and the time for language lessons have changed many time before. At its final application, there are at least two hours' mandatory English lesson at schools. Coursebooks and teachers have been the main sources of information in these lessons and until recently the schools had to find their books and had their own terms of evaluation while selecting one among many. In general, the government schools take lesson books from the Turkish Ministry of Education (MONE), and the private schools have a list of books for each lesson.

The school teachers have many items starting from the printing quality to content while selecting a good course book for the education period. Literature studies show that; in terms of printing elements, the things to be considered are printing quality, illustrations, color and text font (Cerit and Gökçearslan, 2016) etc. On the other hand, the skills and the way of their presentation, the quality and originality of the exercises, the method of the teaching target language and so many others need to be evaluated under the headline of the content of the course book. In order to carry this process, there is a need for checklist to decide which book is the best. That's why how to evaluate and to define an effective book for the teaching-learning activities have been a subject for many studies. There are many different checklists for examining the content and the cover of a course book from many different perspectives. Education and Science Employees Union [Eğitimiş], 2018; Coşkun, 2018; Oruç and Yavuz, 2013; Radic-Bojanic Topalov, 2016).

Tekir and Arıkan (2007) conducted a study on course books by Turkish writers titled as 'Let's speak English 7' sample. They conducted a survey study with 130 participants. In their study, the attitudes of teachers and students towards the course book were studied and they found that not only teachers but also students had negative feelings towards the course book. Majority of the topics and the activities were found boring. The activities for teaching skills were considered insufficient. Grammar focus was found as not supportive for the target course book. Another study was carried by Haznedar. Haznedar (2008), published an analysis on elementary level course books. It was aimed to make a critical evaluation and the course book was examined in terms of design, organization, methodology, activity types, language content and topics. At the end of the study it was found that the subject is not appropriate for cognitive 
development of the students. The books were supposed to have communicative exercises, and the books were lack of acquiring language skills. In his study, Genç (2002), defined some criteria for a good course book and these were: appropriateness to the school type and lesson hours, being harmony with the teaching plan, being friendly to the student budget, useful in the teaching-learning environment and having a student friendly working plan. Başaranol (2017), added a criterion to the examination of values in English course books in his study and conducted a content analysis on the course books. The course book was found insufficient in terms of having universal values in the presented units and it was suggested to enrich the course book with the integration of values such as honesty, equality, hospitality and humanity.

Şimşek and Dündar (2017), investigated EFL course book research trends in Turkey by the help of graduate thesis between the years 2001 and 2013. It was found that there were 54 graduate theses between these years. The research revealed many factors related with course books; the tendency of course books evaluation mainly based on qualitative research design. The books were grouped as local and global books. Local book's content and publishing process were carried at local markets while global books had international brands at these stages. The local course book was found effective, but they were defined as poor at design, methodology and skills while the global books were considered to have integrated skills, authenticity and cultural context. The need of a depth, long-term and document analysisbased researches were mentioned in the study. Some of the studies preferred to consult the opinions of the teachers after they used the target course book and then discussed whether it was a good choice or not, along with possible suggestions. (Kılıçkaya, 2019; Yaşar, 2015). Kazazoğlu (2010), conducted a study among teachers and their preferences of course books. The study suggested that teacher gave importance to genuineness at most. Another study being carried on the best seller English course books, revealed that teachers were not content with the course books in general (Kayapınar, 2009). Some studies on the other hand, focused on the opinions of the students. Hopa (2019), tried to find the elements making an EFL Textbook effective from the perspectives of students. The students attended a semi-structured interview and the data showed that they gave importance to have global and local issues in a course book. The course book should present a content helping not only skill development but also personal development on the way of becoming a world-citizen.

Ertürk (2013), examined EFL course book titled 'Unique 6'from the perspectives of teachers and students. The students had positive attitudes towards activities and language type, on the other hand teachers have positive attitudes towards language type and skills. Uçkun and Onat (2008), conducted a study on the significance of authentic tasks in English course books. They revealed that course books should be adjustable and give freedom to teachers to adapt the content they need. Some other studies had focused on the cultural elements and their places in the course books (Ulum and Bada, 2016). Cultural elements were important because they were considered to have positive effects on the teaching-learning process. (Dimici, Y1ld1z, and Başbay, 2018; Çelik and Erbay, 2013; Özcan, 2019).

Aytuğ (2017) examined the course book of Anatolian high schools at her master thesis. She carried her study with 60 English teachers with conducted interviews in June 2006. The participants of the study mentioned that a course book should have colorful, motivating and attractive color. Illustrations were found important along with the headings, letterings and 
placement of the texts. These elements result with high cost as mentioned by the participants. The other important finding was that majority of the participants choose a communicative methodology and a skill-balanced content course book. For the ELT teachers on the study, a book should give equal importance to four skills of language (listening, reading, speaking and writing). The study also supported the variety of cultural elements in course book. The skills in the course books were also examined by many researchers in terms of effectiveness over the language development of the students (Korkmaz and Mede, 2017; Uçkun and Onat, 2008; Telemeci and Er, 2018). For reading skill it was important to be authentic, to have different reading skills, to have a word recycle exercise routine and to be appropriate for the pedagogical development of the target students. For speaking skills, it was suggested that there is a need to integrate spoken grammar into the textbooks in context of Turkey (Karaata and Soruç, 2012).

All of these studies suggest that the course book is a continuous and also an important element of the language teaching activities. The government's policy on delivering books to the students free of charge does not affect the private schools and they demand course books which are expensive for many parents. In this study it was aimed to examine the English course book selected for a known and prestigious private school in Sinop. The harmony of the content and skills along with the education program was tried to be evaluated besides an external evaluation of the book.

\section{Methods}

This study was carried in a qualitative method. In this study, 'document analysis' method was preferred. Document analysis method enables to reach the target points without observations and interviews (Özkan U. B., 2019). It covers the analysis of the printed materials which contain the related information on the target subject. Lesson books can be classified as textbased, secondary and institutional documents. (Kıral, 2020). The process of the analysis was carried by following these steps: 1 . Selection of the document, understanding it with a deeper analysis, content analysis, if available transform the texts into numeric settings, evaluation of the results.

In this study the answers for the following research questions are examined:

1. Is the course book adequate in terms of integration of design, graphic elements and content?

2. Does the course book present the subjects and skills in harmony with the program outcomes?

3. What are the proportions of the language skills in the course book?

\section{Data Source}

In this study 'Reading Power English Book' is preferred. It has twelve units and 222 pages. It is used for eleventh grade students at private schools in Turkey. In each unit there are four parts which of each consist of two different contents. The course book is printed by the National Geographic in 2015. 


\section{Data Collection Process}

Due to the qualitative design of the study the student book is analyzed according to the document analysis criteria. It is aimed to define the skills which are presented in the lesson book and the way of conveying the skills in the book besides their harmony with the aims and targets of the curriculum. Two different researchers were investigated the course book in terms of internal and external qualities defined for the course books by MONE in the Criteria for Evaluation of a Course Book Handbook (1.8)

\section{Data Analysis Process}

The lesson book is subjected to internal and external evaluation. The criteria for the following questions are tried to be examined in terms of external evaluation: book cover, page layout, colors, symbols and directions headlines. The internal evaluation on the other hand is examined in terms of language skills and their harmony with the learning outcomes. The external and internal evaluation processes are carried by two different researchers who are experienced in their fields more than ten years and still active in teaching system. The researchers gave their scores for the related title from 1 (very poor) to 5 (very good) separately and then the mean scores for the criteria titles were taken into consideration.

\section{Findings}

The first research question was related with the external evaluation of the book. The back and front cover of the book was a photographic one. The subject course book includes geographic, cultural and art elements on the cover. The 'Cloud Gate' is presented in the book. There was a logo of National Geographic on the cover. On the back cover there is a space for publisher information and barcode.

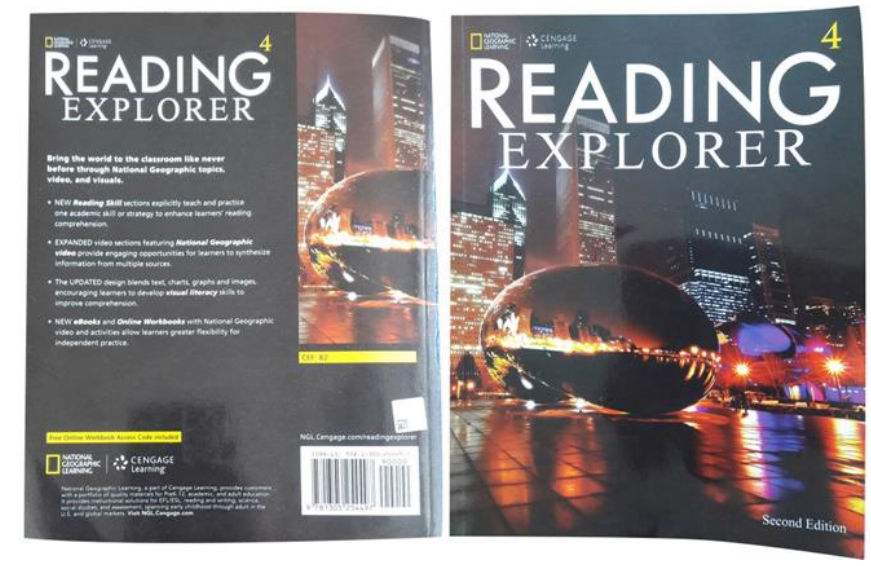

Picture 1. The Front and Back Cover of the Course Book

Typographic features of the book were examined also, and the text quality was good to read, and the color was also helping the user. The white color on the black floor was helpful in reading. The name of the book, 'Reading Explorer', catch the attention of the students with its Sans Serif and non-Sans Serif fonts. At the back cover there were bold characters among the normal characters and it also got attention of the students. The passages were written without Sans Serif and it was sometimes hard to read for long a time. 


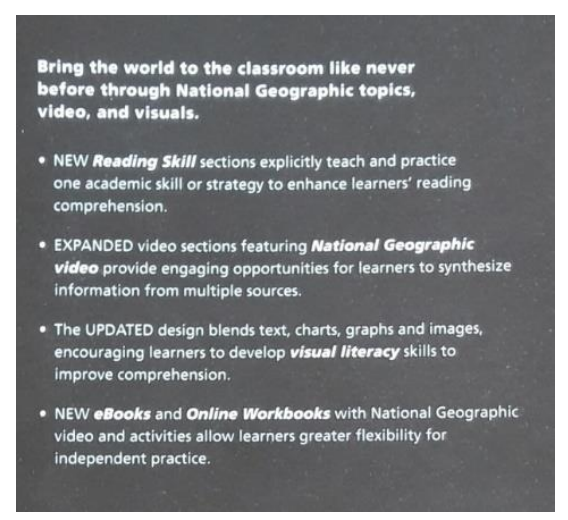

Picture 2. The Written Text Area of the Back Cover

When the inner pages were examined it was seen that there were high resolution photographs that present a background story for the units. The headlines of the units were written on the right side of the page and the text form is preferred without Sans and at different font size. The headlines of the units were written in white and yellow colors on black background and the attention of the reader directed to the written texts. The photographs were combined with the headlines and it was tried to have a more spacious area on the pages. Also, the text style and the page layout made the text and the page more readable.

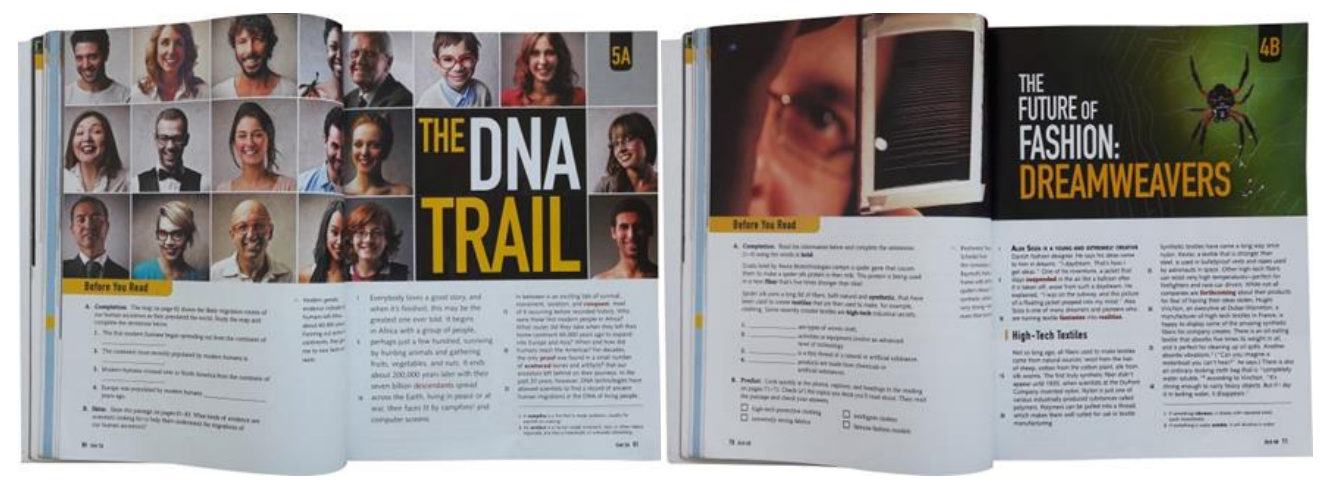

Picture 3. Inner Pages of the Course Books (Introduction to the Subject)

The pages of the inner units can be seen in Picture 4. The pictures were given at left sides and the texts were given alongside the pictures in two columns and it is left aligned. This situation gave a disorganized view to the pages and the page numbers were given at bottom right as in the traditional style.

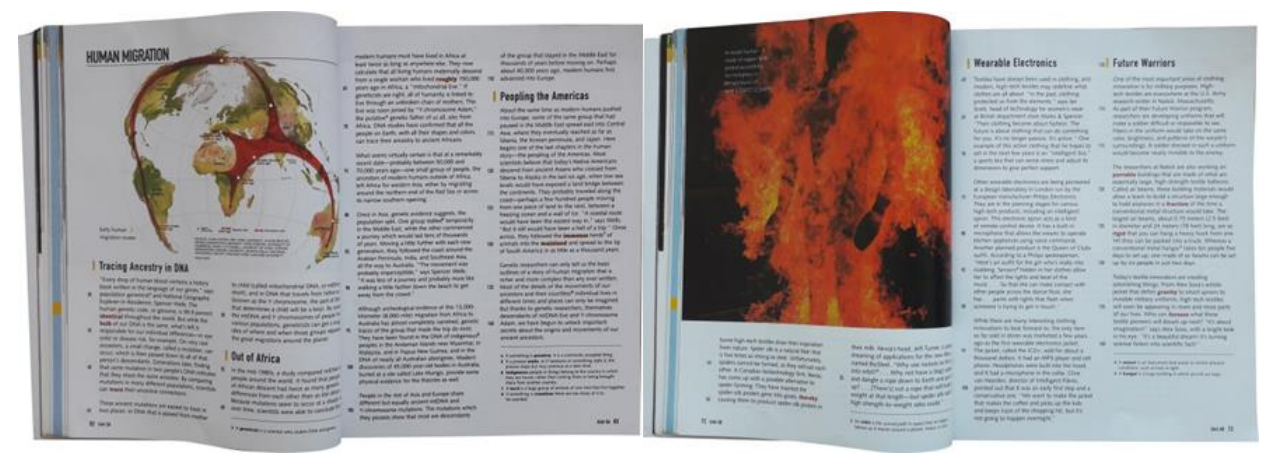

Picture 4. Inner Page Layout and Design of the NG Course Book 
The exercises were given in separate parts and there were parts to repeat the subject. The page layout was the same as in the inner pages where the subject is given. There were enough spaces for taking notes in the exercise pages. The fonts and the style were easy to read and were not eye tiring.

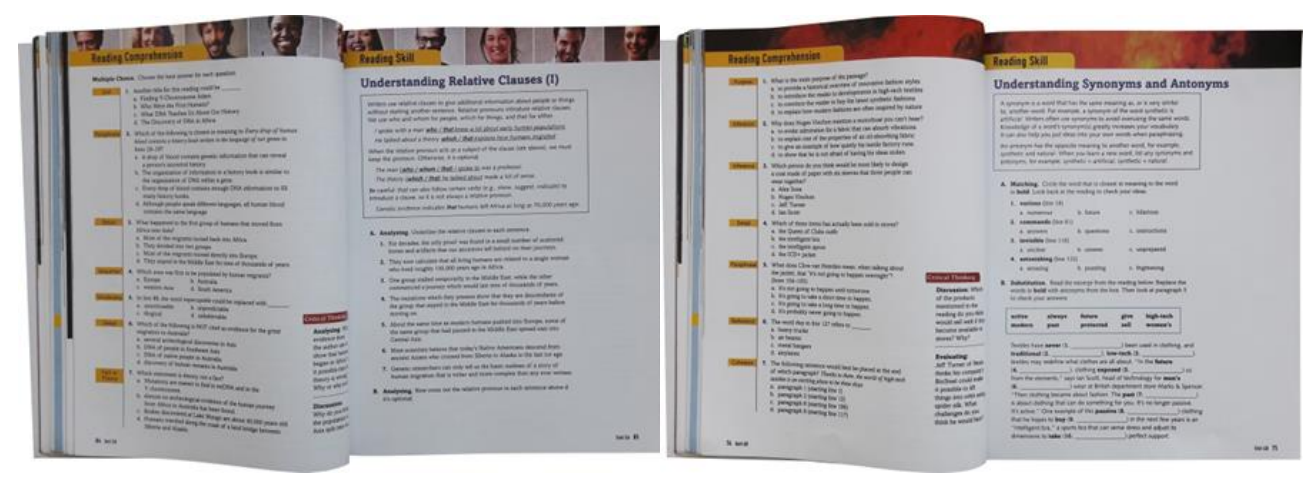

Picture 5. Samples of Inner Pages of the NG Course Books (The Exercises of the Subject)

The other element for the external evaluation was colors. The pages of the target book showed that the colors were yellow and white, the texts were black, and the important words were given in red colors. Yellow colors were especially selected in order to appeal the senses and took attention. They were also stimulant and easy to code and break the monotony of the reading text.

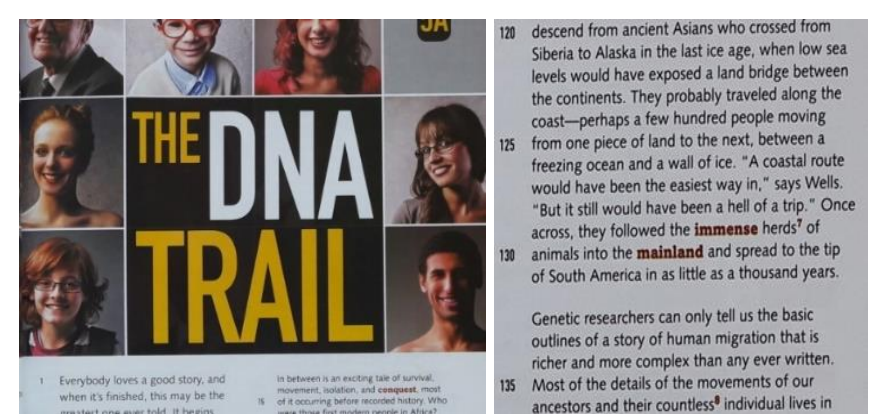

Picture 6. Sample Pages for the Unit Headlines and the Important Words in Red

The red color emphasized the importance of the word and it gets attention of the reader. It helped reader to memorize the word easily and symbolizes that the word was important for the target subject. The other two elements were symbols and directions. The book mainly used photographs as symbols for the target unit and the directions were mainly given in the texts in a traditional manner either in the right or left side of the related visual.
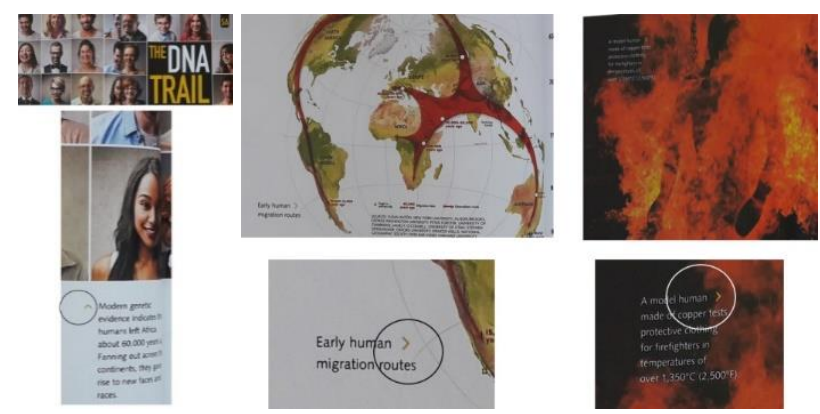

Picture 7. Samples for Main Directions and Symbols 
Other focus point of the study was the internal quality of the book and it was examined in terms of language skills and their way of presentation. The English Language Outcomes for the eleventh-grade students were defined for each skill in Major Philosophy and General Objectives of 9th-12th Grades English Curriculum (1.2). The outcomes for listening skills were: the students would be able to detect information about related topics, build relationship between the conversations, recognize vocabulary indicating the sequence of events, identify expressions related to unreal past events, find out the speakers 'intention, mood and purposes, recognize information about the description of monument or a historic site, identify the lexis and jargon on the conversation and identify the topic and the main idea of the conversations, recorded text/video.

The outcomes to be mastered at speaking skill were to be able to talk about future plans and predictions, take part in a dialogue about likes dislikes, interests and preferences, to be able to talk about past habits, share their personal experiences in the past, to talk about their regrets and wishes about past events, criticize an action in the past, exchange opinions about outdoor/extreme sports and will be able to clarify a well-known/common person or a place.

The reading skills to be mastered were; the students will be able to analyze different texts from newspapers/websites, identify lexis and expressions related to past abilities, analyze a short story, identify thesis statement, topic sentences, supporting points and examples in a given sample essay about a challenge. The students would be able to order events, analyze a text to distinguish the expressions used to express wishes, regrets and unreal past. The students would be able to find out specific information in a text, to distinguish the main idea from supporting details in a text about the effects of values on societies.

The writing skills were these; to be able to write CVs/letters of intent for different contexts, to write a paragraph about their interests and abilities, to be able to complete the missing information, to write their opinions and regrets according to given context, write a letter to criticize an event/organization. The students would be able to write blogs, posts recommending places, to write a report on the interview they have made, write a text about their environments.

The course books presented acquisitions at each unit. These were: at Unit 1 The Power of Image: being able to understand the word with multiple meanings, scan for specific details. At Unit 2- Love and Attraction: the students could distinguish facts from theories, recognize figurative language. At Unit 3-Food and Health: understanding cause and effect relationships, arguments for and against an issue; recognizing collocations and understanding synonyms and antonyms were the acquisitions of Unit 4 . Students would be able to understand relative clauses and synthesize information at unit 5 , besides recognizing conditional relationship and sequencing information were acquirements of Unit 6- Conservation Challenges. At Unit 7 titled as Ritual Lives students would be able to understand the words from context and know the word roots and affixes. At Unit 8 and 9 the students would be able to understand the structure of relative clauses. At Unit 10 and 11 the aim was to teach the references to people and to things beyond the text. At Unit 12 the students were to understand the quantitative and qualitative data at the passages. 
Table 1. The Numbers of the Skill Related Exercises

\begin{tabular}{lccccc}
\hline Number of the Unit & $\begin{array}{c}\text { Reading } \\
\text { Skill }\end{array}$ & $\begin{array}{c}\text { Listening } \\
\text { Skill }\end{array}$ & $\begin{array}{c}\text { Speaking } \\
\text { Skill }\end{array}$ & $\begin{array}{c}\text { Writing } \\
\text { Skill }\end{array}$ & Grammar Corner \\
\hline 1 Power of Image & 8 & 3 & 3 & - & - \\
2 Love and Attraction & 8 & 3 & 2 & - & - \\
3 Food and Health & 10 & 3 & 2 & - & - \\
4 Design and & 13 & 3 & 2 & - & - \\
Engineering & 11 & 3 & 3 & - & - \\
5 Human Journey & 12 & 3 & 3 & - & - \\
6 Conservation & 14 & 3 & 1 & - & - \\
Challenge & 13 & 3 & 2 & - & - \\
7 Ritual Lives & 14 & 3 & 4 & - & - \\
8 Investigations & 12 & 3 & 3 & - & - \\
9 Rediscovering the & 11 & 3 & 5 & - & - \\
Past & 13 & 3 & 5 & & - \\
10 Earth and Beyond & & & & & - \\
11 Green Concerns & 12 Living Longer & &
\end{tabular}

The internal evaluation was also carried in detail. The lesson book was to present the language skills equally and the activities should be designed with this aim (Genç, 2002). The subjected book had listening exercises at each unit. These exercises were presented in video activities. The exercise was divided into three parts; before, during and after watching. The before part was mostly focused on vocabulary activities and warm-up exercises for listening part. The students also did exercise while watching and they mainly focus on comprehension types. While watching exercises consisted of fill-in-the-blanks, true or false and sequencing. These activities were designed for B1-B2 level students. The level of Turkish students at eleventh grade was generally A2 level so these exercises were suitable for the students.

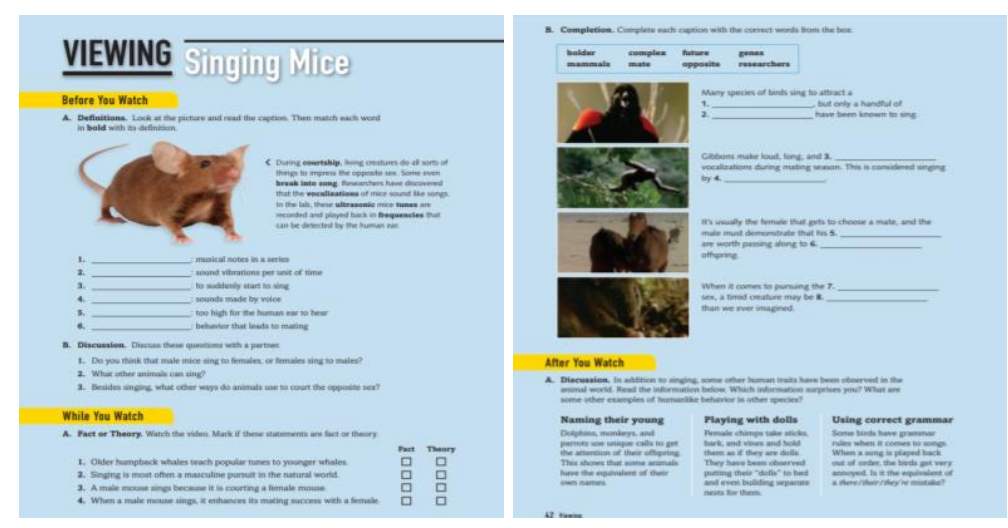

Picture 8. Sample of Listening Skill

Speaking skill was another skill is to be mastered in English. The book had one part for speaking skills under the discussion headline. The discussion part encouraged students to 
compare, analyze and share their ideas. From Unit 1 to Unit 12 the students practiced speaking skill either by making comparisons and defining the related problem or by sharing their experiences and ideas. Some of the exercises demanded students to speak mutually via directions like; explain your reasons, share your experiences and discuss with a group.
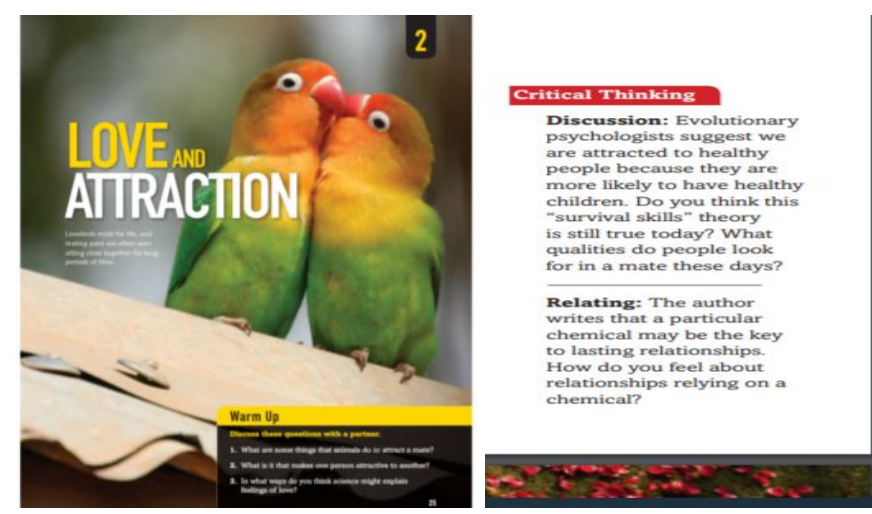

Picture 9. Sample of Speaking Skill

There was not a definite or systematic symbol for speaking parts and it was mainly based on the teacher directions and questions. The speaking skills had a general pattern and it did not have an approach as step by step or form basic to complicated ones. Some exercises were based on cultural elements and some were on personal experiences. The target population however consisted of students living in a small city and the main connection or experience can be achieved via online environments.

The other language skill was reading, and it was seen that the book was mainly based on this skill. All units were arranged based on reading skill and had a very detailed exercise pattern to develop it. All units had warm-up exercises. The reading passages had the order before reading, reading comprehension and vocabulary practices. When warm-up exercises were examined, it was seen that at the beginning of each unit there was a question part.
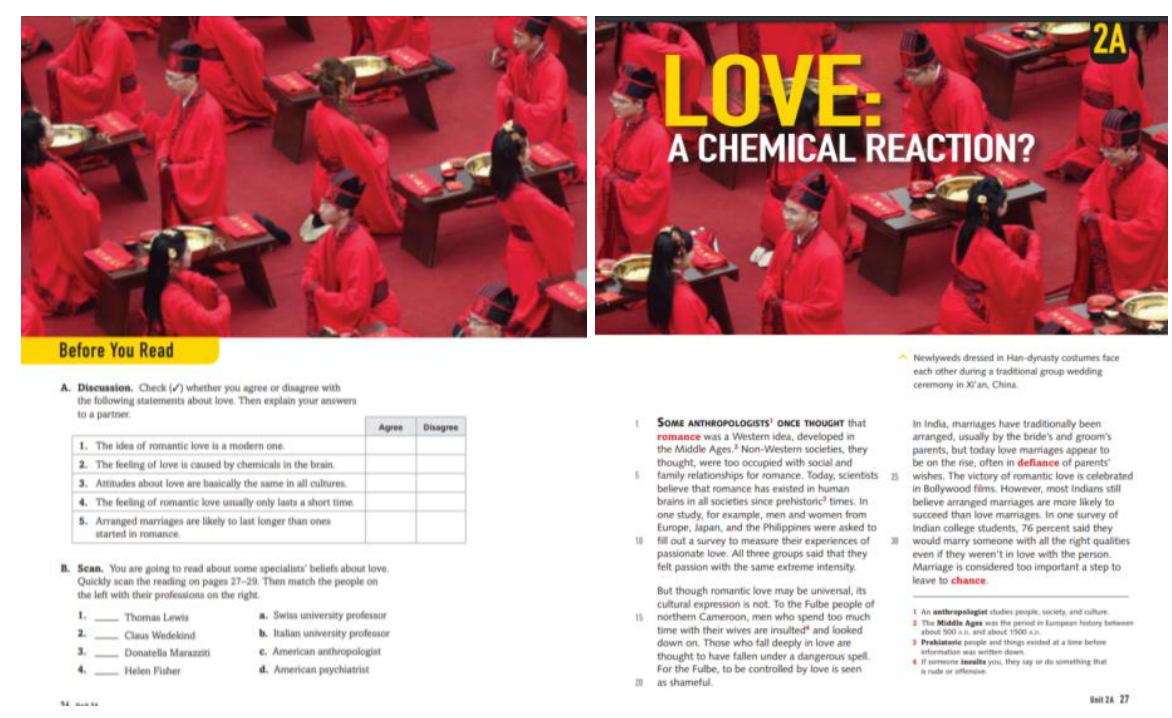

Picture 10. Sample of Reading Skill

For example, at Unit 1 the students were prepared for the reading passage with 'Wh- 
questions. At Unit 1B pre-reading activity was a vocabulary matching activity and a discussion part. Besides the vocabulary activities there were skimming and scanning activities to prepare students for the reading passages. At every unit the professional and related photographs gave clues about the related subject. These pictures took attention of the students and help them to understand the general information or the main frame of the reading text. Reading passages were relatively long for the allotted lesson time. They included the target words in different colors, and they were also written in bold letters. The lines were numbered, and these numbers helped students to find the related lines and answer the questions for the reading comprehension questions. The multiple-choice questions were labelled as purpose, vocabulary, sequence, detail, reference, interference, cohesion, gist and paraphrase, etc. The reading skill was also developed with scanning, contemplation, analyzing and matching exercises for the after reading part. It is clearly seen that the book is focused on reading skills.

The last language skill was writing skill. The book did not have any part or exercise which was related to writing skill. The book had activities mainly for reading skills, the number of activities for reading skill was 139 the listening skill had 36 activities and the speaking skill had 38 activities. The themes of the book were presented with reading skills and the book focused on teaching vocabulary, scanning and skimming, understanding words from the context etc. Themes and the content were found in harmony and the themes were supported by the content. For example, in Unit 3 the theme was defined as 'Food and Health' and it was conveyed by two different reading passages and their headlines are 'How Safe is Our Food?'. Under this headline the students were supposed to understand the cause and effect relationships. The second reading passage was about 'genetically modified food' and at this part the students were to understand arguments for and against an issue. This type of exercises was also given at other units.

\section{Discussion}

The course books are important elements to carry out the teaching activities and most of the teaching activity is based on course books. The studies showed that there was not a perfect course book for every term or people, but the target was to meet the most of the outcomes by the help of fruitful methods. This analysis showed that selected course book was not a successful one in teaching English as a foreign language. The subject course book did not meet the requirements to teach four skills. In terms of outline evaluation, the subject course book used photographic images. The back and front cover of the book was a photographic one. Photographic images were visual languages that help communication with senses, culture and facts (Başal, 2015). The 'Cloud Gate' and other pictures, along with logos were important but the color is more important than the color itself (Ritchey, 2016). The color is essential in terms of having harmony and guiding the user. The subject course book gives the user a visual control over the pages. The information on the pages helps users to convey the message easily. The images were used as a way of communication and it should be the way to be presented in course books (Gavin Ambrose, 2013a). Course book met the requirement for this item with a bunch of pictures and texts. The studies showed that Serif formed texts are directive and help the reader to read easily (Gavin Ambrose, 2013b). The long texts were hard for the reader without Sans Serif in the subject course books. The headlines of the units were written in white 
and yellow colors on black background and the attention of the reader directed to the written texts. The other item to be researched under the outline evaluation of the course book was colors. Colors were important to take attention, add animation and present a unified picture. Colors were also important in order to organize the elements on the pages, grouping the defined information and being able to code the target information (www.understandinggraphics.com). The color combination of the book was found very good when the scores of the researchers were taken into consideration. It was seen that both of the researcher gave 5 points for this headline. The course book was prepared by National Geography and it was not surprising to reach such a result.

The external evaluation was done, and it was seen that the book had good quality for the book cover, page layout and colors. But the course book was found weak in terms of symbols and infographics. Infographics given in the textbooks, were found motivating and effective in teaching a foreign language (Bozoval1, 2016). Graphics and pictures were found effective at $\% 65$ rate in learning a foreign language (Karg1, 2017). Yet it can be said that, the course book did not pay attention on the symbols and infographics. As a result of the external evaluation; the course book was found good in terms of printing quality and graphic elements. It had pictures related to the subject and the relation was clear to understand. The organization of the pictures and the page was good for eye quality. It was easy to read and follow the text and subject. The colors and directive symbols were understandable and strategically placed to make the most of the page. The infographics were consistent with the general design and the content in terms of internal evaluation of the course book.

The four language skills were crucial elements of a language learning process (Aydoğan and Akbarov, 2014). Reading skills were in majority for the subject course book. The length of the passages however was too long for the lesson time. It was inevitable having gaps between the texts. The teacher should organize activities to help the students remember the subject. The writing skill was not given at all and speaking and listening skills were also few in number. In order to teach other skills, the teacher should adapt them into lesson by themselves. There are some technics to adapt the material such as adding (extending and expanding), deleting (subtracting), modifications and others but these were all elements that take time and need extra hours to works for teachers (Kara, 2019). Language skills in the target course book was not equally shared and the teacher was the main source for acquisition of the skills other than reading. In Turkey the course books were found lack of unity in teaching all of the language skills at the same course book (Demirci and Tavil, 2015). This study showed consistency with the other studies as it was defined the focused skill was reading skill. Other than language skills the cultural elements were also examined. It was found that the course book did not have national features but there were plenty of cultural elements of other cultures. The units had an international tendency rather than giving a national feature or cultural element of the Turkish nation. It can be considered as useful in terms of learning more about the other nations but it was not suitable for the national aims of the English language program defined by Ministry of Education. The outcomes of language education were defined to have national elements in it and the course book was found weak under this item. In conclusion, private schools 'course book selection in Sinop was found weak and not effective to teach the target language but the book was effective in terms of graphic design and graphical elements. 


\section{Author Contributions}

The authors carried the process simultaneously in the research. They each have contributed to the study at $50 \%$. The first author is responsible for the internal evaluation, related literature and discussion part while the second author is responsible for the external evaluation, related literature and discussion part.

\section{Conflict of Interest}

The authors of the study certify that they have no affiliations with or involvement in any organization or entity with any financial interest (such as honoraria; educational grants; participation in speakers 'bureaus; membership, employment, consultancies, stock ownership, or other equity interest; and expert testimony or patent-licensing arrangements), or nonfinancial interest (such as personal or professional relationship, affiliations, knowledge or beliefs) in the subject matter or materials discussed in the manuscript.

\section{References}

Akbar, R. (2016). An analysis of selected eleventh grade English textbooks. Journal of English and Education, 4(1), 109-126.

Aydoğan, H. \& Akbarov, A. A. (2014). The four basic language skills, whole language \& intergrated skill approach in mainstream university classrooms in Turkey. Mediterranean Journal of Social Sciences ,5(9), 672-680.

Aytuğ, S. (2017). An EFL textbook evaluation study in Anatolian high schools: 'new bridge to success for 9th grade new beginners'. Unpublished master's thesis. Bilkent Üniversitesi, Eğitim Bilimleri Enstitüsü, İstanbul.

Baleghizadeh, S. \& Saharkhiz , A. (2012). Linguistic imperialism and EFL textbooks: the case of American English file. e-İnternational Journal of Education Research, 3(2), 36-49.

Başal, P. (2015). Ortaokul İngilizce ders kitaplarında kültür öğelerinin incelenmesi. Unpublished master's thesis. Yıldız Teknik Üniversitesi Sosyal Bilimler Enstitüsü, İstanbul.

Başaranol, V. (2017). Ortä̈ğetim ders kitaplarmın temel değerler açısından incelenmesi. Unpublished master's thesis. Abant İzzet Baysal Üniversitesi, Eğitim Bilimleri Enstitüsü, Bolu.

Bozovalı, E. (2016). Otantik kaynaklar olarak görsel bilgi grafiklerinin yabancı dil öğretiminde kullanılması. SOBIDER Sosyal Bilimler Dergisi, 36, 206-216. DOI: 10.16990/SOBIDER.175

Cerit, E. \& Gökçearslan, A. (2016). Türkiye'de yayınlanan Türk masal kitaplarının grafik tasarım öğeleri açısından incelenmesi: Keloğlan masalları örneği. Sanat ve Tasarım Dergisi, 17, 49-73. DOI: 10.18603/std.71419

Coşkun, D. (2018). Multimodal analysis of Turkish EFL textbooks for elementary, intermediate and high school grades. Unpublished master's thesis, Süleyman Demirel Üniversitesi, Eğitim Bilimleri Enstitüsü, Isparta.

Çelik, S. \& Erbay, Ş. (2013). Cultural perspectives of Turkish ELT coursebook: do standardized teaching texts incorporate intercultural features? Ĕgitim ve Bilim, 39(167), 336-351. 
An EFL coursebook evaluation in terms of design and language:

Private school samples in Sinop

Demirci, D. \& Tavil, Z. M. (2015). Are the skills really integrated in coursebooks? A sample case-yes you can A1.2. Educational Research and Reviews, 10(12), 1599-1632. DOI: 10.5897/ERR2015.2259

Dimici, K., Yıldız, B. \& Başbay, A. (2018, Aralık). An analysis of an English coursebook (English file) in terms of multiculturalism. Dil Ĕ̆itimi ve Araştırmaları Dergisi, 4(3), 175-200. DOI:10.31464/jlere.426780

Dinçer, A. (2014). A rhetorical analysis of texts in ELT coursebooks in terms of figurative language. Unpublished doctoral dissertation. Çukurova Üniversitesi Sosyal Bilimler Enstitüsü Adana.

Eğitim ve Bilim İş Görenleri Sendikası. (2018). Kitap inceleme raporu. Ankara: Eğitim-İş.

Elmal1, A. (2019). The analysis of the speaking activities in English coursebooks of ministry of education in the context of classroom-based assessment activities. Unpublished doctoral dissertation. İstanbul Üniversitesi, Cerrahpaşa Eğitim Enstitüsü, İstanbul.

Ertürk, H. (2013). An EFL course book evaluation: unique 6, teachers 'and students perspectives. Unpublished master's thesis. Necmettin Erbakan Üniversitesi, Eğitim Bilimleri Enstitüsü. Konya.

Gavin Ambrose, P. H. (2013a). Layout. İstanbul: Literatür.

Gavin Ambrose, P. H. (2013b). The fundamentals of creative design. İstanbul: Literatür.

Gavin Ambrose, P. H. (2013c). Yaratıcı tasarımın temelleri. İstanbul: Literatür.

Genç, A. (2002). İlk ve ortaöğretim okullarında yabancı dil ders kitabı seçimi. Hacettepe Üniversitesi Ĕ̆itim Fakültesi Dergisi, 22, 74-81.

Güneş, B. (2009). 1945-1980 arası Türkiye'de İngilizce eğitimi. Unpublished master's thesis. Süleyman Demirel Üniversitesi, Sosyal Bilimler Enstitüsü, Isparta.

Haznedar, B. (2008, 1-5 May). Türkiye'de yabancı dil eğitimine ilişkin değerlendirmeler: ilköğretim ingilizce ders kitaplarının incelenmesi. Presented at 1st International Congress of Educational Research, Çanakkale.

Hopa, M. (2019). What makes an EFL textbook effective? learner perceptions about characteristics of effective EFL textbooks. Unpublished master's thesis. Orta Doğu Teknik Üniversitesi, Sosyal Bilimler Enstitüsü, Ankara.

Işık, A. (2013). How are ELT materials chosen in high schools? Some suggestions. Hacettepe Üniversitesi Ĕ̆itim Fakültesi Dergisi, 28(1), 165-176.

Kara, S. (2019). Pre-service teachers' coursebook evaluation and adaptation: an evaluation of 9th grade english coursebook. Journal of the Faculty of Education, 20(2), 564-577. DOI: 10.17679/inuefd.482825

Karaata, C. \& Soruç, A. (2012). The missing gap between spoken grammar and English textbooks in Turkey. Dumlupınar Üniversitesi Sosyal Bilimler Dergisi, 32(2), 9-18.

Karg1, B. (2017, 22-23 September). Yabancı dil öğreniminde resim-yazi bağlamında çizgi romanlar. Presented at1st International Black Sea Conference on Language and Language Education. Samsun. 
Kaya, A. (2017). Examining the integration of intercultural communicative competence in ESL/EFL textbooks. Unpublished master's thesis, Bahçeşehir Üniversitesi, Eğitim Bilimleri Bölümü, İstanbul.

Kayapınar, U. (2009). Coursebook evaluation by english teachers. İnönü University Journal of the Faculty of Education, 10(1), 69-78.

Kazazoğlu, S. (2010). İngiliz dili eğitimi bölümlerinde görev yapan ingilizce öğretmenlerinin ders kitabı kullanımına ilişkin tercihleri. Dil Dergisi, 148, 53-66.

Kazma, P. (2015). Grafik tasarımcilar, yazarlar ve yayınevleri ekseninde Türkiye'de kitap kapak tasarımları. Unpublished master`s thesis. Haliç Üniversitesi, Sosyal Bilimler Enstitüsü, İstanbul.

Kılıçkaya, F. (2019). Pre-service English teachers'views on coursebook evaluation and designing supplementary materials. Kastamonu Eğitim Dergisi, 27(2), 523-536. DOI:10.24106/kefdergi.2574

Kıral, B. (2020). Nitel bir veri analizi yöntemi olarak Döküman Analizi. Siirt Üniversitesi Sosyal Bilimler Enstitüsü Dergisi, 8(15), 170-189.

Korkmaz, H. G. \& Mede, E. (2017). Investigating the effectiveness of the reading materials in an English coursebook: a case from Turkey. Mustafa Kemal Üniversitesi Ĕ̆itim Fakültesi Dergisi, 4(2), 9-27. DOI:10.2166/muefd.304280

Milli Eğitim Bakanlığı. (2012). Meb Mevzuat. Retrieved 07 14, 2020, from http://mevzuat.meb.gov.tr/dosyalar/1605.pdf

Milli Eğitim Bakanlığı. (2018). İngilizce dersi öğretim programı. Retrieved 07 14, 2020, from Meb Mufredat: http://mufredat.meb.gov.tr/Dosyalar

Oruç, N. \& Yavuz, B. (2013). Yabancı dil öğretiminde ders kitabı seçimi. Uluslararası Sosyal Araştırmalar Dergisi, 6(27), 398-407.

Öğretim Programları İzleme ve Değerlendirme Sistemi. (2018). İngilizce. Ankara: Milli Eğitim Bakanlı̆̆1. $\quad$ Retrieved $11 \quad 20, \quad 2020, \quad$ from https://mufredat.meb.gov.tr/ProgramDetay.aspx?PID=342

Özcan, E. N. (2019). The analysis of global values in ELT coursebooks published by the ministry of national education for 2018-2019 academic years. Unpublished master`s thesis. Uludag Üniversitesi, Eğitim Bilimleri Enstitüsü. Bursa.

Özkan, R. \& Tutkun, S. B. (2014). İlköğretim sosyal alan ders kitaplarının boyut ve içerik tutarlılığ1 açısından incelenmesi. International Journal of Social Sciences, 24, 371-386. DOI:10.9761/JASSS2169

Özkan, U. B. (2019). Ĕ̆itim bilimleri araştırmaları için doküman inceleme yöntemi. Ankara: Pegem Yayıncilik.

Radic-Bojanic, B. B. \& Topalov, J. P. (2016). Textbooks in EFL classroom: defining, assessing and analyzing. Zbornik Radova Filozofskog Fakulteta u Prištini, 46(3), 137-153. DOI10.5937/ZRFFP46-12094

Ritchey, R. (2016). Worlds of fiction. Retrieved 07 15, 2020, from https://rachaelritchey.com/2016/05/12/the-importance-of-color-in-book-cover-design/ 
Şahin, M. (2014). Öğretim materyallerin öğrenme-öğretme sürecindeki işlevine ilişkin öğretmen görüşlerinin analizi. Kastamonu Ĕ̆itim Dergisi, 23(3), 995-1012.

Şimşek, M. R. \& Dündar, E. (2017, April). Investigating EFL coursebook research in turkey: trends in graduate theses of the 2001-2013 period. Kuram ve Uygulamada Eğitim Bilimleri, 17(3), 969-1014. DOI:10.12738/estp.2017.3.0090

Tekir, S. \& Arıkan, A. (2007). An analysis of English language teaching coursebooks by turkish writers: "let's speak English 7" example. Journal of Human Sciences, 4(2), 1-18.

Telemeci, B. \& Er, K. O. (2018). A1.1 düzeyi "schritt fur schritt deutsch" isimli ortaöğretim almanca ders kitabının dört dil becerisi ve içerik açısından incelenmesi. Turkish Studies, 13(11), 1249-1278. DOI: 10.7827/TurkishStudies.13412

Uçkun, B. \& Onat, Z. (2008). Yabancı dil kitaplarında özgün metin ve özgün görev kullanımının önemi: bir kitap incelemesi. Gaziantep Üniversitesi Sosyal Bilimler Dergisi, 7(1), 419-164.

Ulum, Ö. G. \& Bada, E. (2016). Cultural elements in EFL course books. Gaziantep University Journal of Social Studies, 15(1), 15-26.

UNESCO. Guidelines for book cover design. Retrieved 07 15, 2020, from http://www.unesco.org/new/fileadmin/MULTIMEDIA/HQ/ERI/pdf/bookcoverguidelin es_final_en_MA.pdf

Visual Desgn. (2005). 10 reasons to use color. Retrieved from http://understandinggraphics.com/design/10-reasons-to-use-color/

Yaman, İ. (2018). Türkiye'de İngilizce öğrenmek: zorluklar ve fırsatlar. Rumelide Dil ve Edebyat Araştırmaları Dergisi, 11, 161-175. DOI: 10.29000/rumelide.417491

Yaşar, Ö. (2015). İlkokul 2. sınıf fun with teddy İngilizce ders kitabının öğretmen görüşleri doğrultusunda değerlendirimesi. Türkiye Sosyal Araştırmalar Dergisi, 19(1), 329-348.

Zohrabi, M. (2011). Coursebook development and evaluation for English for general purposes course. English Language Teaching, 4(2), 213-222. DOI: 10.5539/elt.v4n2p213 